\title{
The Effects of Polymorphisms in One-carbon Metabolism Genes on Manifestation of Ichthyosis Vulgaris
}

\author{
Olena Fedota ${ }^{1}$, Iurii Sadovnychenko, ${ }^{1,2 *}$, Liliia Chorna ${ }^{3}$, Larysa Roshchenyuk ${ }^{4,5}$, Vitalii Vorontsov ${ }^{5}$, Pavlo Ryzhko ${ }^{5}$, \\ Ivanna Haiboniuk ${ }^{3}$, Sergei Belyaev ${ }^{6}$, Igor Belozorov ${ }^{7}$, Halyna Makukh ${ }^{3}$

\begin{abstract}
${ }^{1}$ Department of Obstetrics and Gynecology, School of Medicine, V.N. Karazin Kharkiv National University, Kharkiv, Ukraine; ${ }^{2}$ Department of Medical Biology, $5^{\text {th }}$ Faculty of Foreign Students Training, Kharkiv National Medical University, Kharkiv, Ukraine; ${ }^{3}$ Genetic Research Laboratory, Institute of Hereditary Pathology, National Academy of Medical Sciences of Ukraine, Lviv, Ukraine; ${ }^{4}$ Department of Dermatology, Venereology and AIDS, $2{ }^{\text {nd }}$ Medical Faculty, Kharkiv National Medical University, Kharkiv, Ukraine; ${ }^{5}$ Regional Clinical Dispensary for Skin and Venereal Diseases no. 1, Kharkiv, Ukraine; ${ }^{6}$ Department of Genetics, Obstetrics, Gynecology and Fetal Medicine, Faculty of General Practice-Family Medicine, Kharkiv Medical Academy of Postgraduate Education, Kharkiv, Ukraine; ' 7 Department of Surgical Diseases, Operative Surgery and Topographical Anatomy, School of Medicine, V.N. Karazin Kharkiv National University, Kharkiv, Ukraine
\end{abstract}

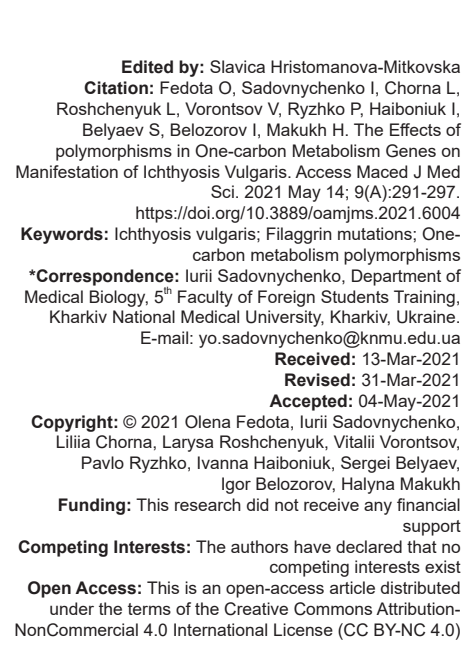

Introduction

One of the largest groups of skin and subcutaneous tissue diseases is genodermatoses, which includes disorders of keratinization such as ichthyoses [1]. The prevalence of ichthyosis vulgaris $(Q$ 80.0, OMIM $146700)$, which is regarded as the most common type of the disease, varies across countries [2], [3]. Ichthyosis vulgaris is caused by loss-of-function mutations in the gene encoding crucial epidermal protein filaggrin (FLG, 1q21.3, OMIM 135940). Lack of filaggrin results in keratin filament disorganization, abnormal architecture of lipid matrix, scaling, dry skin condition, and impaired skin barrier function [3], [4], [5], [6], [7].

\begin{abstract}
BACKGROUND: Ichthyosis vulgaris is the most common type of Mendelian disorders of cornification, caused by loss-of-function mutations in the gene encoding epidermal protein filaggrin $(F L G)$, namely R501X and 2282del4.

patients with ichthyosis vulgaris.

METHODS: Thirty-one patients with ichthyosis vulgaris, 7 their FLG heterozygous relatives without symptoms of disorder, and 150 healthy controls were enrolled in the study. FLG null mutations - R501X (rs61816761) and MTHFR A1298C (rs1801131), MTR A2756G (rs1805087), and MTRR A66G (rs1801394) - were analyzed by a AA:AC:CC - 52.9\%:47.1\%:0.0\%; MTR A2756G AA:AG:GG - 70.3\%:23.5\%:5.9\%; and MTRR A66G AA:AG:GG - 23.4\%:52.9\%:23.5\%. The frequencies of MTR 2756AA and MTRR 66GG genotypes were 1.4-1.6 times higher in affected individuals heterozygous for 2282del4 than in patients with other FLG genotypes. In affected 2282del 4 heterozygotes, the frequency of MTR 2756AA genotype was 1.6 times greater than in healthy controls $(p<0.01)$. The strongest association was found between MTHFR 677CT/MTHFR 1298AA/MTR 2756AA/MTRR 66AG genotype heterozygotes for the FLG 2282del4 mutation (OR 2.80-11.23). The most probable predisposing genotype is 677CT/1298AA/2756AA+AG/66AG.
\end{abstract}

Segregation analysis of ichthyosis vulgaris confirmed a monogenic (Mendelian) autosomal semidominant mode of inheritance and its association with FLG null mutations [8]. In populations of European ancestry, two most common mutations are 2282del4 (rs558269137) and R501X (rs61816761) [7]. Despite the fact that in heterozygotes, penetrance of the mutations ranges from $73 \%$ for 2282 del 4 to $96 \%$ for R501X [7], [9], any explanation of the difference between the frequencies of homo- and heterozygotes for FLG null mutations $(13.0 \%)$ and prevalence of ichthyosis (1.3\%) has not been proposed yet [2], [7], [10]. At the same time, epigenetic studies of eczema and atopic dermatitis demonstrated that the risk of the diseases is associated with methylation level of FLG gene [11], [12], [13]. It 
might indicate the role of one-carbon metabolism in the regulation of FLG gene expression [1], [14]

Our previous research has shown that carriers of FLG 2282del4 mutation, who were heterozygous for C677T polymorphism in the MTHFR gene (1p36.22, OMIM 607093), were 7 times as likely to develop ichthyosis as subjects with wild-type 677CC genotype [15]. It was also found that an elevated plasma homocysteine level impaired not only the metabolism of sulfur-containing amino acids, methionine, and cysteine, but also keratin molecules [16], [17], [18] that might exacerbate the effects of FLG null mutations. Every of single nucleotide polymorphisms (SNPs) of one-carbon metabolism genes - MTHFR C677T (rs1801133) and A1298C (rs1801131), MTR A2756G (rs1805087) and MTRRA66G (rs1801394) — are associated with plasma homocysteine level [19], [20]. The only significant model for hyperhomocysteinemia is a four-locus model that includes SNPs of MTHFR, MTR, and MTRR [21].

Therefore, one-carbon metabolism genes could be considered as candidate regulatory genes of network for keratinization.

The aim of the present study was to analyze the effects of MTHFR, MTR, and MTRR gene polymorphisms in patients with ichthyosis vulgaris.

\section{Materials and Methods}

Patients with ichthyosis vulgaris were recruited from the Regional Clinical Dermatological and Venereological Dispensary no. 1 and dermatological and venereological dispensaries of Kharkiv region, Ukraine. Genomic DNA was isolated from blood samples of 31 patients with ichthyosis vulgaris and 7 their first-degree relatives without ichthyosis using salting-out method. The detection of FLG null mutations (R501X and 2282del4) and one-carbon metabolism gene polymorphisms (MTHFR C677T, MTHFRA1298C, MTRA2756G, and MTRRA66G) was performed by polymerase chain reaction-restriction fragment length polymorphism (PCR-RFLP) assay with optimal primers (Metabion, Germany). The PCR products were digested with Hinfl, Mboll, Haelll, and Ndel restriction endonucleases (Thermo Fisher Scientific, USA) [22], [23], [24], [25], [26], [27]. The digested PCR products were separated on $2.5 \%$ agarose gel (Amresco, USA).

The normality of distribution of continuous variables was tested by Shapiro-Wilk test. Correlations between groups were assessed by Pearson and Spearman correlation. The genotype frequencies were analyzed using Fisher's angular transformation. When multiple hypothesis tests were performed, a Bonferroni corrected p-value was used.

Differences in variables were statistically analyzed with Chi-square test with the values predicted by the assumption of Hardy-Weinberg equilibrium. Odds ratios (ORs) with 95\% confidence interval $(\mathrm{Cl})$ were used to evaluate the association between one-carbon metabolism gene polymorphisms and risk of ichthyosis vulgaris.

All data analyses were performed using Statistica Basic Academic (version 13.3, TIBCO Software Inc., Palo Alto, CA, USA). The linkage disequilibrium (LD) parameters D' and $r^{2}$ were estimated and haplotype block analyses were performed in Haploview (version 4.2, Broad Institute, Cambridge, MA, USA).

Informed consent was obtained from all individuals involved in the study. The research was carried out in accordance with the basic bioethical principles of the World Medical Association's Declaration of Helsinki (2000, as amended in 2008), the Universal Declaration on Bioethics and Human Rights (1997), and the Convention on Human Rights and Biomedicine of the Council of Europe (1997). All procedures were approved by the local Ethics Committee of Kharkiv National Medical University.

\section{Results}

The results of a literature-based analysis of the geographical distribution of the MTHFR A1298C, MTR A2756G, and MTRR A66G alleles and genotypes frequencies in the northern hemisphere are reported in Table 1. The negative correlation was observed between latitude and frequency of MTRR66AG genotype (Pearson $r=-0.6523, p=0.041)$. Previously, we found a negative relationship between the latitude and frequencies of MTHFR 677T allele and MTHFR 677CT genotype [53].

The geographic distribution of alleles and genotypes frequencies of one-carbon metabolism gene polymorphisms was also compared to plasma homocysteine levels across Europe using data provided in the related studies [52]. Homocysteine concentrations showed positive correlations with the frequencies of MTR 2756A allele and MTR 2756AA genotype (Pearson $r=0.689, p=0.040$ and Pearson $r=0.751$, $p=0.020$, respectively), and negative correlations with the frequencies of MTR 2756G allele and MTRR 66GG genotype (Pearson $r=-0.737, p=0.024$ and $r=-0.771$, $p=0.015$, respectively).

Based on our data, the penetrance of ichthyosis vulgaris in individuals with 2282del4/2282del4, 2282del4/R501X, and R501X/wt FLG genotypes would be considered a complete one, but in individuals with 2282del4/wt genotype, it was estimated at $67 \%$.

The allele and genotype frequencies of onecarbon metabolism polymorphisms in patients with ichthyosis vulgaris and their relatives from Kharkiv region are reported in Table 2 . Significant deviation from 
Hardy-Weinberg equilibrium was detected for the MTHFR C677T genotypes in patients with ichthyosis vulgaris.

The frequencies of MTR 2756AA genotype and MTRR 66GG genotype were 1.4-1.6 times higher in affected individuals heterozygous for 2282del4 than in patients with other FLG genotypes (Table 2). In 2282del4 heterozygotes, the frequency of MTR 2756AA genotype in affected individuals was 1.6 times greater than in unaffected ones, but the frequency of MTRR 66GG genotype in the first group was 1.8 times lower than in the second one (Table 2). In affected 2282del4 heterozygotes, the frequency of MTR 2756AA genotype was 1.6 times greater than in healthy controls (Table 2).

To estimate the association between polymorphisms in one-carbon metabolism genes and ichthyosis vulgaris manifestation in individuals with 2282del4/wt genotype, we calculated OR for the different disease models representing from one to four variants of folate metabolism genes. Table 3 shows the only statistically significant results. In single-locus models, MTHFR C677T polymorphism was significantly associated with ichthyosis vulgaris in the overdominant genetic model (OR 3.600, 95\% Cl 1.207-10.712, $p=0.032$ ). In two-locus models, a significant increase in disease manifestation was associated with MTHFR 677CT/MTHFR 1298AA + AC (OR 4.393; 95\% Cl 1.468-13.139, $\mathrm{p}=0.008)$ and MTHFR 677CT/MTR 2756AAgenotypes (OR 4.239, 95\% Cl 1.495-12.018, $p=$ $0.007)$. The best three-locus model was one representing heterozygosity for polymorphisms MTHFR C677T and MTRRA66G, and homozygosity for the MTHFRA1298C polymorphism (OR 7.636, 95\% Cl 2.338-24.943, p = $0.001)$. The strongest association was found between MTHFR 677CT/MTHFR 1298AA/MTR 2756AA/MTRR 66AG genotype and ichthyosis (OR 11.231, 95\% Cl 2.512-50.209, $p=0.002)$. These results suggest that for the heterozygotes for FLG 2282del4 mutation the best model of clinical manifestation of ichthyosis is a fourlocus model for folate metabolism genes.

The MTHFR 677CT/MTHFR 1298AA/MTR 2756AA+AG/MTRR66AG genotype is most likely genotype associated with manifestation of ichthyosis vulgaris.

The MTHFR, MTR, and FLG genes are located on the chromosome 1, so LD might underlie this association. In individuals with FLG mutations, two LD blocks were revealed (Figure 1). The first one consisted

Table 1: Geographic distribution of genotype and allele frequencies of one-carbon metabolism single nucleotide polymorphisms in Europe

\begin{tabular}{|c|c|c|c|c|c|c|c|c|c|c|c|c|c|c|c|c|c|c|c|c|c|}
\hline \multirow[t]{4}{*}{ Country } & \multicolumn{10}{|c|}{ MTHFR } & \multirow{2}{*}{\multicolumn{5}{|c|}{$\begin{array}{l}\text { MTR } \\
\text { A2756G } \\
\end{array}$}} & \multirow{2}{*}{\multicolumn{5}{|c|}{$\begin{array}{l}\text { MTRR } \\
\text { A66G } \\
\end{array}$}} & \multirow[t]{4}{*}{ Source } \\
\hline & \multicolumn{5}{|c|}{ C677T } & \multicolumn{5}{|c|}{ A1298C } & & & & & & & & & & & \\
\hline & \multicolumn{3}{|c|}{ Genotype } & \multicolumn{2}{|l|}{ Allele } & \multicolumn{3}{|c|}{ Genotype } & \multicolumn{2}{|l|}{ Allele } & \multicolumn{3}{|c|}{ Genotype } & \multicolumn{2}{|l|}{ Allele } & \multicolumn{3}{|c|}{ Genotype } & \multicolumn{2}{|c|}{ Allele } & \\
\hline & $\overline{C C}$ & $C T$ & $T T$ & $\bar{C}$ & $T$ & $\overline{A A}$ & $A C$ & $C C$ & $\bar{A}$ & $C$ & $\overline{A A}$ & $A G$ & GG & $\bar{A}$ & G & $\overline{A A}$ & $A G$ & GG & $\bar{A}$ & $G$ & \\
\hline Scotland & 48.7 & 41.4 & 9.9 & 69.4 & 30.6 & 46.5 & 43.3 & 10.2 & 68.2 & 31.9 & 65.5 & 31.5 & 3.0 & 81.3 & 18.7 & 19.6 & 47.8 & 32.6 & 43.5 & 56.5 & [28], [29] \\
\hline Denmark & 50.3 & 41.4 & 8.3 & 71.0 & 29.0 & 46.0 & 41.3 & 12.7 & 66.7 & 33.3 & 62.6 & 33.5 & 3.9 & 79.3 & 21.4 & 37.6 & 43.2 & 19.3 & 59.2 & 40.9 & $\begin{array}{l}{[30],[31],} \\
{[32]}\end{array}$ \\
\hline England & 46.2 & 42.7 & 11.1 & 67.6 & 32.4 & 47.8 & 40.2 & 12.0 & 67.9 & 32.1 & 63.8 & 32.3 & 3.9 & 80.0 & 20.0 & 37.1 & 47.2 & 15.6 & 60.8 & 39.3 & [32], [33] \\
\hline Ireland & 46.4 & 43.6 & 10.0 & 68.2 & 31.8 & 49.4 & 41.8 & 8.8 & 70.3 & 29.7 & 63.7 & 32.0 & 4.3 & 79.7 & 20.3 & 37.4 & 46.6 & 16.0 & 60.7 & 39.3 & $\begin{array}{l}{[34],[35],} \\
{[36]}\end{array}$ \\
\hline Poland & 49.5 & 42.8 & 7.8 & 70.9 & 29.2 & 43.7 & 46.2 & 10.0 & 66.9 & 33.2 & 65.8 & 30.8 & 3.3 & 81.3 & 18.8 & 27.5 & 46.7 & 25.8 & 50.8 & 49.2 & $\begin{array}{l}{[37],[38],} \\
{[39]}\end{array}$ \\
\hline Germany & 48.7 & 40.8 & 10.6 & 69.0 & 31.0 & 50.0 & 42.0 & 8.0 & 71.0 & 29.0 & 62.3 & 34.0 & 3.8 & 79.3 & 20.8 & 17.7 & 53.6 & 28.8 & 4.44 & 55.6 & $\begin{array}{l}{[40],[41],} \\
{[42]}\end{array}$ \\
\hline France & 37.6 & 52.6 & 9.8 & 63.9 & 36.1 & 51.5 & 40.9 & 7.6 & 72.0 & 28.0 & 66.2 & 30.0 & 3.9 & 81.1 & 18.9 & 28.7 & 50.7 & 20.6 & 54.1 & 46.0 & $\begin{array}{l}{[34],[43],} \\
{[44]}\end{array}$ \\
\hline Austria & 43.0 & 43.5 & 13.5 & 64.7 & 35.3 & 48.2 & 41.6 & 10.2 & 69.0 & 31.0 & - & - & - & - & - & 19.8 & 50.3 & 30.0 & 45.0 & 55.1 & [45], [46] \\
\hline Croatia & 46.1 & 44.7 & 9.2 & 68.4 & 31.6 & 46.7 & 42.7 & 10.7 & 68.0 & 32.0 & 61.7 & 34.0 & 4.3 & 78.7 & 21.3 & 24.7 & 47.7 & 27.7 & 48.5 & 51.5 & [47], [48] \\
\hline Italy & 29.0 & 54.8 & 16.1 & 56.5 & 43.6 & 47.7 & 35.5 & 16.8 & 65.5 & 34.5 & 67.5 & 29.2 & 3.3 & 82.1 & 17.9 & 26.3 & 52.5 & 21.2 & 52.5 & 47.5 & $\begin{array}{l}\text { [34], [49], } \\
\text { [50], [51] }\end{array}$ \\
\hline$r$ & 0.754 & -0.717 & -0.643 & 0.648 & -0.648 & -0.210 & 0.501 & -0.335 & 0.107 & -0.098 & -0.281 & 0.334 & -0.059 & -0.221 & 0.271 & 0.383 & -0.652 & -0.149 & 0.286 & -0.285 & \\
\hline$p$-value & 0.012 & 0.020 & 0.045 & 0.043 & 0.043 & 0.561 & 0.141 & 0.344 & 0.769 & 0.788 & 0.464 & 0.379 & 0.880 & 0.568 & 0.480 & 0.275 & 0.041 & 0.682 & 0.423 & 0.424 & \\
\hline
\end{tabular}

Table 2: Genotype and allele frequencies, and Hardy-Weinberg P values for one-carbon metabolism single nucleotide polymorphisms in ichthyosis vulgaris cases and controls

\begin{tabular}{|c|c|c|c|c|c|c|c|c|c|c|c|c|c|c|c|c|c|c|c|c|c|c|}
\hline \multirow[t]{3}{*}{ Filaggrin genotype } & \multirow[t]{3}{*}{ Phenotype } & \multirow[t]{3}{*}{ Ratio } & \multicolumn{5}{|c|}{ MTHFR C677T } & \multicolumn{5}{|c|}{ MTHFR A1298C } & \multicolumn{5}{|c|}{ MTR A2756G } & \multicolumn{5}{|c|}{ MTRR A66G } \\
\hline & & & \multicolumn{3}{|c|}{ Genotype } & \multicolumn{2}{|l|}{ Allele } & \multicolumn{3}{|c|}{ Genotype } & \multicolumn{2}{|l|}{ Allele } & \multicolumn{3}{|c|}{ Genotype } & \multicolumn{2}{|l|}{ Allele } & \multicolumn{3}{|c|}{ Genotype } & \multicolumn{2}{|l|}{ Allele } \\
\hline & & & $\overline{\mathrm{CC}}$ & CT & TT & $\mathrm{C}$ & $T$ & $\overline{\mathrm{AA}}$ & $A C$ & $\mathrm{CC}$ & $\mathrm{A}$ & C & $\overline{\mathrm{AA}}$ & $A G$ & GG & $\mathrm{A}$ & G & $\overline{\mathrm{AA}}$ & $A G$ & GG & $\mathrm{A}$ & G \\
\hline $\begin{array}{l}\text { 2282del4/2282del4, } \\
\text { R501X/2282del4, }\end{array}$ & Affected & $\begin{array}{l}\text { Frequency } \\
\text { (\%) }\end{array}$ & 26.7 & 66.7 & 6.7 & 60.0 & 40.0 & 57.1 & 35.7 & 7.1 & 75.0 & 25.0 & 50.0 & 42.9 & 7.1 & 71.4 & 28.6 & 35.7 & 50.0 & 14.3 & 60.7 & 39.3 \\
\hline $\begin{array}{l}R 501 X / w t \\
(n=14)\end{array}$ & & ${ }^{\text {H'WE }} P$ & $<0.00$ & & & 1.000 & & 0.893 & & & 1.000 & & 0.882 & & & 1.000 & & 0.891 & & & 1.000 & \\
\hline $\begin{array}{l}2282 \text { del } 4 / w t \\
(n=17)\end{array}$ & & $\begin{array}{l}\text { Frequency } \\
(\%)\end{array}$ & 29.4 & 70.6 & 0 & 64.7 & 35.3 & 52.9 & 47.1 & 0 & 76.5 & 23.5 & 70.3 & 23.5 & 5.9 & 83.9 & 16.1 & 23.4 & 52.9 & 23.5 & 50.0 & 50.0 \\
\hline & & ${ }^{\text {H'WE }} P$ & 0.013 & & & 1.000 & & 0.261 & & & 1.000 & & 0.497 & & & 1.000 & & 0.841 & & & 1.000 & \\
\hline & & ${ }^{R 501 x} P$ & 0.552 & & & 0.325 & & 0.405 & & & 0.729 & & $<0.001$ & & & $<0.001$ & & 0.006 & & & 0.032 & \\
\hline $\begin{array}{l}2282 \mathrm{del} / 4 / w t \\
(n=7)\end{array}$ & Unaffected & $\begin{array}{l}\text { Frequency } \\
(\%)\end{array}$ & 57.1 & 28.6 & 14.3 & 71.4 & 28.6 & 42.9 & 42.9 & 14.3 & 64.3 & 35.7 & 42.9 & 57.1 & 0 & 71.4 & 28.6 & 0 & 57.1 & 42.9 & 28.6 & 71.4 \\
\hline & & ${ }^{\text {HWE }} P$ & 0.011 & & & 1.000 & & 0.801 & & & 1.000 & & 0.103 & & & 1.000 & & 0.265 & & & 1.000 & \\
\hline & & ${ }^{\mathrm{R} 501 \mathrm{x}} P$ & $<0.00$ & & & 0.011 & & 0.009 & & & 0.025 & & 0.149 & & & 1.000 & & $<0.00$ & & & $<0.001$ & \\
\hline & & ${ }^{22821 \mathrm{~V}} P$ & $<0.00$ & & & 0.137 & & 0.042 & & & 0.011 & & $<0.001$ & & & 0.006 & & $<0.00$ & & & $<0.001$ & \\
\hline $\begin{array}{l}w t / w t \\
(n=150)\end{array}$ & & $\begin{array}{l}\text { Frequency } \\
(\%)\end{array}$ & 54.7 & 40.0 & 5.3 & 74.7 & 25.3 & 42.7 & 44.7 & 12.7 & 65.0 & 35.0 & 42.7 & 38.7 & 18.7 & 62.0 & 38.0 & 25.3 & 37.3 & 37.3 & 44.0 & 56.0 \\
\hline & & ${ }_{\mathrm{R} 501 x} P$ & $<0.00$ & & & $<0.001$ & & 0.010 & & & 0.036 & & 0.012 & & & 0.052 & & $<0.00$ & & & 0.001 & \\
\hline & & ${ }^{22821 \mathrm{~V}} P$ & $<0.00$ & & & 0.022 & & 0.038 & & & 0.016 & & $<0.001$ & & & $<0.001$ & & 0.003 & & & 0.227 & \\
\hline & & ${ }^{2282 \mathrm{H}} P$ & $<0.00$ & & & 0.457 & & 0.869 & & & 0.881 & & 0.975 & & & 0.052 & & 0.254 & & & $<0.001$ & \\
\hline
\end{tabular}


Table 3: Association between one-carbon metabolism polymorphisms and ichthyosis vulgaris risk in FLG 2282del4 heterozygotes

\begin{tabular}{|c|c|c|c|c|c|c|c|c|}
\hline \multicolumn{4}{|c|}{ Genotype } & \multirow{3}{*}{$\begin{array}{l}\text { FLG } \\
(\mathrm{n}=17)\end{array}$} & \multirow{3}{*}{$\begin{array}{l}\text { Controls } \\
(n=150)\end{array}$} & \multirow{3}{*}{$\begin{array}{l}\text { Odds } \\
\text { ratios }\end{array}$} & \multirow{3}{*}{$\begin{array}{l}\text { confidence } \\
\text { interval }\end{array}$} & \multirow{3}{*}{ p-value } \\
\hline MTHFR & MTHFR & MTR & MTRR & & & & & \\
\hline C677T & A1298C & A2756G & A66G & & & & & \\
\hline $\mathrm{CT}$ & - & - & - & 12 & 60 & 3.600 & $1.207-$ & 0.032 \\
\hline- & - & $\mathrm{AA}$ & - & 12 & 64 & 3.223 & $\begin{array}{l}10.712 \\
1.082- \\
9.614\end{array}$ & 0.036 \\
\hline CT & AA & - & - & 7 & 26 & 3.339 & $\begin{array}{l}1.163- \\
9.582\end{array}$ & 0.025 \\
\hline CT & $A A+A C$ & - & - & 12 & 53 & 4.393 & $\begin{array}{l}1.468- \\
13.139\end{array}$ & 0.008 \\
\hline CT & - & AA & - & 6 & 26 & 4.239 & $\begin{array}{l}1.495- \\
12.018\end{array}$ & 0.007 \\
\hline CT & - & $A A+A G$ & - & 9 & 49 & 3.779 & $\begin{array}{l}1.320- \\
10.817\end{array}$ & 0,013 \\
\hline CT & - & - & $A A+A G$ & 9 & 37 & 3.436 & $\begin{array}{l}1.236- \\
9.549\end{array}$ & 0.018 \\
\hline CT & $A A+A C$ & $A A+A G$ & - & 9 & 43 & 2.799 & $\begin{array}{l}1.014- \\
7.733\end{array}$ & 0.047 \\
\hline CT & AA & - & $A G$ & 6 & 10 & 7.636 & $\begin{array}{l}2.338- \\
24.943\end{array}$ & 0.001 \\
\hline - & AA & AA & $A G$ & 5 & 10 & 5.833 & $\begin{array}{l}1.714- \\
19.853\end{array}$ & 0.005 \\
\hline CT & - & AA & $A G$ & 5 & 10 & 5.833 & $\begin{array}{l}1.714- \\
19.853\end{array}$ & 0.005 \\
\hline CT & - & $A A+A G$ & $A A+A G$ & 8 & 31 & 3.412 & $\begin{array}{l}1.217- \\
9.569\end{array}$ & 0.020 \\
\hline CT & AA & AA & $A G$ & 4 & 4 & 11.213 & $\begin{array}{l}2.512- \\
50.209\end{array}$ & 0.002 \\
\hline
\end{tabular}

of SNPs of the MTHFRgene (rs1801133 and rs1801131) that demonstrated strong linkage $\left(D^{\prime}=1.00 ; L O D=2.32\right.$; $\left.r^{2}=0.195\right)$. The second block included mutations in the FLG gene (rs558269137 and rs61816761) with incomplete linkage $\left(D^{\prime}=1.00 ; L O D=1.53 ; r^{2}=0.109\right)$.

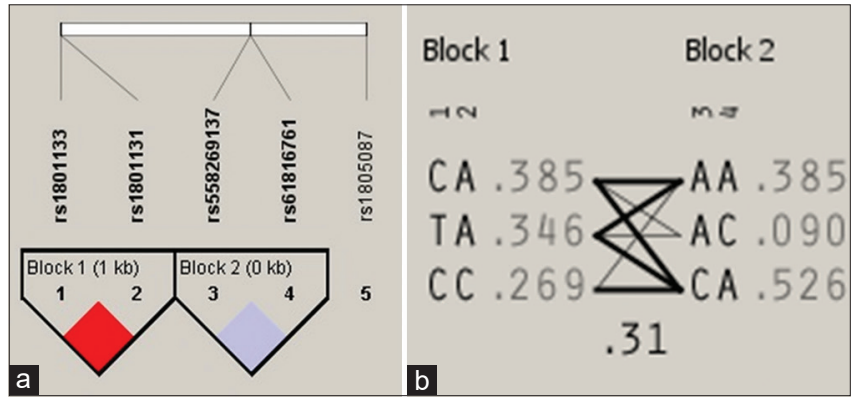

Figure 1: Linkage disequilibrium: Linkage disequilibrium blocks (a) and haplotypes (b) in individuals with filaggrin mutations. The color scheme shows the strength of linkage between markers: red - a strong linkage $\left(D^{\prime}=1, L O D>2\right)$, lilac - impossibility to calculate the linkage disequilibrium due to low frequency of the minor allele $\left(D^{\prime}=1, L O D<2\right)$. The connections between the $L D$ blocks are shown as thick and thin lines for haplotypes with a frequency $>10 \%$ and $>1 \%$, respectively

\section{Discussion}

The latitudinal features of the distribution of genotype and allele frequencies of one-carbon metabolism genes, as well as plasma homocysteine levels related to these polymorphisms, probably arose as adaptations to different climate conditions and had ethnoterritorial confinement [54], [55]. Thus, they need to be analyzed for each population separately.

In general, the penetrance of FLG 2282del4 mutation obtained in this research corresponds to our previous and literary data [7], [15]. We suggested that folate metabolism polymorphisms could be associated with clinical manifestation of ichthyosis vulgaris in individuals with 2282del4/wt genotype.

It is known that various genotypes for the MTHFR, MTR, and MTRR genes are related to cardiovascular, endocrine, reproductive disorders, certain cancer types, etc. [38], [56], [57], [58], [59], [60], [61], [62], [63], [64], [65], [66], [67], [68].

Polymorphisms of one-carbon metabolism genes and FLG null mutations are associated with the same disorders, including atopic dermatitis, eczema, inflammatory bowel disease, endocrine and gynecological diseases, skin permeability barrier dysfunction, and neoplasms [56], [68], [69], [70], [71], [72], [73]. These all suggest that other SNPs of folate metabolism genes, in addition to the MTHFR C677T variant, might affect FLG gene expression [73].

In our research, a strong association between homocysteine-raising polymorphisms of one-carbon metabolism genes and ichthyosis vulgaris was found in individuals with $F L G$ null mutations.

LD blocks in chromosome 1 were not linked, perhaps because the distance between these loci exceeds $60 \mathrm{~kb}$ [74].

We tested a hypothesis about folate metabolism polymorphisms impact on the phenotypic expression of FLG null mutations in patients with ichthyosis vulgaris for England and Scotland only. This was because all the necessary data on the prevalence of the disease and frequencies of the FLG mutations and one-carbon metabolism polymorphisms were available for this region [2], [10], [75]. The frequencies of $F L G$ heterozygotes and the predisposing genotype MTHFR 677CT/MTHFR 1298AA/MTR 2756AA+AG/MTRR 66AG are 0.13 and 0.092 in the region; thus, the combined probability of the clinical manifestation of ichthyosis vulgaris should be 0.012 , that is not statistically different from the prevalence of the disease reported for the region $-0.013(p=0.857)$.

\section{Conclusion}

Various genotypes of one-carbon metabolism genes increase the risk of ichthyosis in heterozygotes for the FLG 2282del4 mutation (OR 2.799-11.231). The most probable predisposing genotype is 677CT/1298AA/2756AA+AG/66AG.

\section{References}

1. GBD 2017 Disease and Injury Incidence and Prevalence Collaborators. Global, regional, and national incidence, prevalence, 
and years lived with disability for 354 diseases and injuries for 195 countries and territories, 1990-2017: A systematic analysis for the global burden of disease study 2017. Lancet. 2018;392(10159):1789858. https://doi.org/10.1016/S0140-6736(18)32279-7

PMid:30496104

2. Brown SJ, Relton CL, Liao H, Zhao Y, Sandilands A, Wilson IJ, et al. Filaggrin null mutations and childhood atopic eczema: A population-based case-control study. J Allergy Clin Immunol. 2008;121(4):940-6. https://doi.org/10.1016/j.jaci.2008.01.013 PMid: 18313126

3. Brown SJ, McLean WH. One remarkable molecule: Filaggrin. J Invest Dermatol. 2012;132(3 Pt 2):751-62. https:/doi. org/10.1038/jid.2011.393

\section{PMid:22158554}

4. Hackl EV, Berest VP, Gatash SV. Effect of cholesterol content on gramicidin S-induced hemolysis of erythrocytes. Int J Pept Res Ther. 2012;18(2):163-70. https:/doi.org/10.1007/ s10989-012-9289-9

5. Kezic S, Jakasa I. Filaggrin and skin barrier function. Curr Probl Dermatol. 2016;49:1-7. https://doi.org/10.1159/000441539 PMid:26844893

6. Popov M, Lyadova T, Volobuyeva O, Shepileva N, Kozlov A, Sorokina O. Cytokine production peculiarities in different forms of Epstein-Barr virus infection. Georgian Med News. 2017;2(263):55-9. PMid:28452728

7. Thyssen JP, Maibach HI, editors. Filaggrin: Basic Science, Epidemiology, Clinical Aspects and Management. Heidelberg: Springer; 2014. p. 373.

8. Smith FJ, Irvine AD, Terron-Kwiatkowski A, Sandilands A, Campbell LE, Zhao Y, et al. Loss-of-function mutations in the gene encoding filaggrin cause ichthyosis vulgaris. Nat Genet. 2006;38(3):337-42. https:/doi.org/10.1038/ng1743

PMid: 16444271

9. Palmer CN, Irvine AD, Terron-Kwiatkowski A, Zhao Y, Liao H, Lee $\mathrm{SP}$, et al. Common loss-of-function variants of the epidermal barrier protein filaggrin are a major predisposing factor for atopic dermatitis. Nat Genet. 2006;38(4):441-6. https:/doi.org/10.1038/ng1767 PMid:16550169

10. Brown SJ, Relton CL, Liao H, Zhao Y, Sandilands A, McLean $\mathrm{WHI}$, et al. Filaggrin haploinsufficiency is highly penetrant and is associated with increased severity of eczema: Further delineation of the skin phenotype in a prospective epidemiological study of 792 school children. Br J Dermatol. 2009;161(4):884-9. https:/ doi.org/10.1111/j.1365-2133.2009.09339.x

PMid:19681860.

11. Ziyab AH, Karmaus W, Holloway JW, Zhang H, Ewart S, Arshad SH DNA methylation of the filaggrin gene adds to the risk of eczema associated with loss-of-function variants. J Eur Acad Dermatol Venereol. 2013;27:e420-3. https:/doi.org/10.1111/jdv.12000 PMid:23003573

12. Bin L, Leung DY. Genetic and epigenetic studies of atopic dermatitis. Allergy Asthma Clin Immunol. 2016;12:52. https:// doi.org/10.1186/s13223-016-0158-5 PMid:27777593

13. Lee J, Jang A, Seo SJ, Myung SC. Epigenetic regulation of filaggrin gene expression in human epidermal keratinocytes. Ann Dermatol. 2020;32(2):122-9. https://doi.org/10.5021/ad.2020.32.2.122

14. Crider KS, Yang TP, Berry RJ, Bailey LB. Folate and DNA methylation: A review of molecular mechanisms and the evidence for folate's role. Adv Nutr. 2012;3(1):21-38. https://doi. org/10.3945/an.111.000992 PMid:22332098

15. Fedota AM, Solodyankin AS, Ryzhko PP, Roshenyuk LV, Vorontsov VM, Solodyankina EA. C677T polymorphism of MTHFR gene ichthyosis patients. Bull Probl Biol Med. 2011;2(1):78-81.

16. Nazki FH, Sameer AS, Ganaie BA. Folate: Metabolism, genes, polymorphisms and the associated diseases. Gene. 2014;533(1):11-20. https://doi.org/10.1016/j.gene.2013.09.063 PMid:24091066

17. Borowczyk K, Suliburska J, Jakubowski H. Demethylation of methionine and keratin damage in human hair. Amino Acids. 2018;50:537-46. https://doi.org/10.1007/s00726-018-2545-3 PMid:29480334

18. Borowczyk K, Wróblewski J, Suliburska J, Akahoshi N, Ishii I, JakubowskiH.Mutationsinhomocysteinemetabolismgenesincrease keratin N-homocysteinylation and damage in mice. Int J Genomics. 2018;2018:7570850. https://doi.org/10.1155/2018/7570850 PMid:30345292

19. Cristalli CP, Zannini C, Comai G, Baraldi O, Cuna V, Cappuccilli $\mathrm{M}$, et al.-Methylenetetrahydrofolate reductase, MTHFR, polymorphisms and predisposition to different multifactorial disorders. Genes Genom. 2017;39:689-99. https:// doi.org/10.1007/s13258-017-0552-5

20. Tinelli C, Di Pino A, Ficulle E, Marcelli S, Feligioni M. Hyperhomocysteinemia as a risk factor and potential nutraceutical target for certain pathologies. Front Nutr. 2019;6:49. https://doi.org/10.3389/fnut.2019.00049 PMid:31069230

21. Rossokha ZI, Kiryachenko SP, Gorovenko NJ. The role of MTHFR, MTRR, MTR1 intergenic interaction in the development of folate metabolism disturbance in patients with reproductive disorders. Ukrain Med J. 2018;2(3):1-5.

22. Frosst P, Blom HJ, Milos R, Goyette P, Sheppard CA, Matthews RG, et al. A candidate genetic risk factor for vascular disease: A common mutation in methylenetetrahydrofolate reductase. Nat Genet. 1995;10(1):111-3. https://doi.org/10.1038/ng0595-111 PMid:7647779

23. van der Put NM, Gabreels F, Stevens EM, Smeitink JA, Trijbels FJ, Eskes TK, et al. A second common mutation in the methylenetetrahydrofolate reductase gene: An additional risk factor for neural tube defects? Am J Hum Genet. 1998;62(5):1044-51. https://doi.org/10.1086/301825 PMid:9545395

24. Matsuo K, Suzuki R, Hamajima N, Ogura M, Kagami $Y$, Taji $\mathrm{H}$, et al. Association between polymorphisms of folateand methionine-metabolizing enzymes and susceptibility to malignant lymphoma. Blood. 2001;97(10):3205-9. https://doi. org/10.1182/blood.v97.10.3205

PMid: 11342450

25. Wilson A, Platt R, Wu Q, Leclerc D, Christensen B, Yang H, et al $A$ common variant in methionine synthase reductase combined with low cobalamin (Vitamin B12) increases risk for spina bifida. Mol Genet Metab. 1999;67(4):317-23. https://doi.org/10.1006/ mgme.1999.2879

PMid: 10444342

26. Blanchard C, Stucke EM, Burwinkel K, Caldwell JM, Collins MH Ahrens A, et al. Coordinate interaction between IL-13 and epithelial differentiation cluster genes in eosinophilic esophagitis. J Immunol. 2010;184(7):4033-41. https://doi.org/10.4049/jimmunol.0903069 PMid:20208004

27. Chorna LB, Makukh HV, Akopyan HR, Zastavna DV, Prokopchuk NM. Analysis of MTHFR, MTR, MTRR genetic variations and $\mathrm{FV}$ and FII genesmutationsofcoagulation factors amongwomen with recurrent pregnancy losses. J VN Karazin Kharkiv Natl Univ Biol. 2011;13(947):118-24.

28. Yu L, Li T, Robertson Z, Dean J, Gu NF, Feng GY, et al. No association between polymorphisms of methylenetetrahydrofolate reductase gene and schizophrenia 
in both Chinese and Scottish populations. Mol Psychiatry. 2004;9(12):1063-5. https://doi.org/10.1038/sj.mp.4001566 PMid: 15289817

29. Theodoratou E, Farrington SM, Tenesa A, McNeill G, Cetnarsky] $\mathrm{R}$, Barnetson RA, et al. Dietary Vitamin B6 intake and the risk of colorectal cancer. Cancer Epidemiol Biomarkers Prev. 2008;17(1):171-82. https://doi.org/10.1158/1055-9965.EPI-07-0621 PMid:18199722

30. Kokotas H, Grigoriadou M, Mikkelsen M, GiannouliaKarantana A, Petersen MB. Investigating the impact of the Down syndrome related common MTHFR 677C $>$ T polymorphism in the Danish population. Dis Markers. 2009;27(6):279-85. https:// doi.org/10.3233/DMA-2009-0673

PMid:20075510

31. Bathum L, von Bornemann Hjelmborg J, Christiansen L, McGue M, Jeune B, Christensen K. Methylenetetrahydrofolate reductase $677 \mathrm{C}>\mathrm{T}$ and methionine synthase $2756 \mathrm{~A}>\mathrm{G}$ mutations: No impact on survival, cognitive functioning, or cognitive decline in nonagenarians. J Gerontol A Biol Sci Med Sci. 2007;62A(2):196-201. https://doi.org/10.1093/gerona/62.2.196 PMid:17339646

32. Bethke L, Webb E, Murray A, Schoemaker M, Feychting M, Lönn $S$, et al. Functional polymorphisms in folate metabolism genes influence the risk of meningioma and glioma. Cancer Epidemiol Biomarkers Prev. 2008;17(5):1195-202. https://doi. org/10.1158/1055-9965.EPI-07-2733

PMid:18483342

33. Relton CL, Wilding CS, Laffling AJ, Jonas PA, Lynch SA, Tawn EJ, et al. Gene-gene interaction in folate-related genes and risk of neural tube defects in a UK population. Med Genet. 2004;41(4):256-60. https://doi.org/10.1136/jmg.2003.010694 PMid:15060097

34. Botto LD, Yang Q. 5, 10-methylenetetrahydrofolate reductase gene variants and congenital anomalies: A HuGE review. Am J Epidemiol. 2000;151(9):862-77. https://doi.org/10.1093/ oxfordjournals.aje.a010290

PMid:10791559

35. Mills JL, Molloy AM, Parle-McDermott A, Troendle JF, Brody LC Conley MR, et al. Folate-related gene polymorphisms as risk factors for cleft lip and cleft palate. Birth Defects Res A Clin Mol Teratol. 2008;82(9):636-43. https://doi.org/10.1002/bdra.20491 PMid:18661527

36. O'Leary VB, Mills JL, Pangilinan F, Kirke PN, Cox C, Conley M, et al. Analysis of methionine synthase reductase polymorphisms for neural tube defects risk association. Mol Genet Metab. 2005;85(3):220-7. https://doi.org/10.1016/j.ymgme.2005.02.003 PMid:15979034

37. Seremak-Mrozikiewicz A, Barlik $M$, Borowczak $P$, Kurzawińska G, Kraśnik W, Nowocień G, et al. The frequency of $677 \mathrm{C}>$ T polymorphism of MTHFR gene in the Polish population. Arch Perinat Med. 2013;19(1):12-8.

38. Nowak I, Bylińska A, Wilczyńska K, Wiśniewski A, Malinowski A, Wilczyński JR, et al. The methylenetetrahydrofolate reductase c.c.677 C>T and c.c.1298 A>C polymorphisms in reproductive failures: Experience from an RSA and RIF study on a Polish population. PLoS One. 2017;12(10):e0186022. https://doi. org/10.1371/journal.pone.0186022

PMid:29073227

39. Seremak-Mrozikiewicz A, Bogacz A, Deka-Pawlik A, Klejewski A, Wolski H, Drews $\mathrm{K}$, et al. The polymorphisms of methionine synthase (MTR) and methionine synthase reductase (MTRR) genes in pathogenesis of preeclampsia. J Matern Fetal Neonatal Med. 2017;30(20):1-17. https://doi.org/10.1080/14767 058.2016.1254183

PMid:27806663
40. Kloss M, Wiest $\mathrm{T}$, Hyrenbach $\mathrm{S}$, Werner I, Arnold ML, Lichy C, et al. MTHFR 677TT genotype increases the risk for cervical artery dissections. J Neurol Neurosurg Psychiatry. 2006;77(3):951-2. https://doi.org/10.1136/jnnp.2006.089730 PMid:16844951

41. Kurzwelly D, Knop S, Guenther M, Loeffler J, Korfel A, Thiel E, et al. Genetic variants of folate and methionine metabolism and PCNSL incidence in a German patient population. $J$ Neurooncol. 2010;100(2):187-92. https://doi.org/10.1007/ s11060-010-0154-4

PMid:20237949

42. Gast A, Bermejo JL, Flohr T, Stanulla M, Burwinkel B, Schrappe $\mathrm{M}$, et al. Folate metabolic gene polymorphisms and childhood acute lymphoblastic leukemia: A case-control study. Leukemia. 2007;21(2):320-5. https://doi.org/10.1038/ sj.leu.2404474

PMid: 17136115

43. Niclot S, Pruvot Q, Besson C, Savoy D, Macintyre E, Salles G, et al. Implication of the folate-methionine metabolism pathways in susceptibility to follicular lymphomas. Blood. 2006;108(1):27885. https://doi.org/10.1182/blood-2005-04-1567

PMid: 16410450

44. Küry S, Buecher B, Robiou-du-Pont S, Scoul C, Colman H, Neel TL, et al. Low-penetrance alleles predisposing to sporadic colorectal cancers: A French case-controlled genetic association study. BMC Cancer. 2008;8:326. https://doi.org/10.1186/1471-2407-8-326 PMid: 18992148

45. Födinger $M$, Buchmayer $H$, Heinz $G$, Papagiannopoulos $M$, Kletzmayr J, Rasoul-Rockenschaub $\mathrm{S}$, et al. Effect of MTHFR $1298 \mathrm{~A} \rightarrow \mathrm{C}$ and MTHFR $677 \mathrm{C} \rightarrow$ T genotypes on total homocysteine, folate, and Vitamin B12 plasma concentrations in kidney graft recipients. J Am Soc Nephrol. 2000;11(10):1918-25. PMid:11004224

46. FeixA, WinkelmayerWC, EberleC,Sunder-Plassmann G, Födinger $M$. Methionine synthase reductase MTRR $66 A>G$ has no effect on total homocysteine, folate, and Vitamin B12 concentrations in renal transplant patients. Atherosclerosis. 2004;174(1):43-8. https://doi.org/10.1016/j.atherosclerosis.2003.12.036

PMid:15135249

47. Lovricevic I, Franjic BD, Tomicic M, Vrkic N, De Syo D, Hudorovic N, et al. 5, 10-Methylenetetrahydrofolate reductase (MTHFR) $677 \mathrm{C} \rightarrow \mathrm{T}$ genetic polymorphism in 228 croatian volunteers. Coll Antropol. 2004;28(2):647-54 PMid:15666596

48. Jokić M, Brčić-Kostić K, Stefulj J, Ivković TC, Božo L, Gamulin M, et al. Association of MTHFR, MTR, MTRR, RFC1, and DHFR gene polymorphisms with susceptibility to sporadic colon cancer. DNA Cell Biol. 2011;30(10):771-6. https://doi. org/10.1089/dna.2010.1189

PMid:21438757

49. Motti C, Gnasso A, Bernardini S, Massoud R, Pastore A, Rampa $\mathrm{P}$, et al. Common mutation in methylenetetrahydrofolate reductase. Correlation with homocysteine and other risk factors for vascular disease. Atherosclerosis. 1998;139(2):377-83. https://doi.org/10.1016/s0021-9150(98)00079-3 PMid:9712345

50. Saccucci $P$, Compagnone E, Verrotti A, Galasso C, Curatolo $P$. Lack of association between MTHFR C677T and MTHFRA1298C genetic polymorphisms and mental retardation. Nutr Neurosci. 2008;11(5):241-2. https://doi.org/10.1179/147683008X301595 PMid: 18782485

51. Giusti B, Saracini C, Bolli P, Magi A, Martinelli I, Peyvandi F, et al Early-onset ischaemic stroke: Analysis of 58 polymorphisms in 17 genes involved in methionine metabolism. Thromb Haemost. 2010;104(2):231-42. https://doi.org/10.1160/TH09-11-0748 


\section{PMid:20458436}

52. Dhonukshe-Rutten RA, de Vries $\mathrm{JH}$, de Bree A, van der Put $\mathrm{N}$ van Staveren WA, de Groot LC. Dietary intake and status of folate and Vitamin B12 and their association with homocysteine and cardiovascular disease in European populations. Eur J Clin Nutr. 2009;63(1):18-30. https://doi.org/10.1038/sj.ejcn.1602897 PMid: 17851461

53. Fedota OM, Roshchenyuk LV, Sadovnychenko IA, Merenkova IN, Gontar IV, Vorontsov VM. Analysis of one-carbon metabolism genes and epidermal differentiation complex in patients with ichthyosis vulgaris. Georgian Med News. 2017;264:90-7. PMid:28480858

54. Binia A, Contreras AV, Canizales-Quinteros S, Alonso VA, Tejero ME, Silva-Zolezzi I. Geographical and ethnic distribution of single nucleotide polymorphisms within genes of the folate/ homocysteine pathway metabolism. Genes Nutr. 2014;9(5):421. https://doi.org/10.1007/s12263-014-0421-7 PMid:25106483

55. Jones P, Beckett E, Yates Z, Veysey M, Lucock M. Converging evolutionary, environmental and clinical ideas on folate metabolism. Explor Res Hypothesis Med. 2016;1(3):34-41. https://doi.org/10.14218/ERHM.2016.00003b

56. Liew SC, Gupta ED. Methylenetetrahydrofolate reductase (MTHFR) T677T polymorphism: Epidemiology, metabolism and the associated diseases. Eur J Med Genet. 2015;58(1):1-10. https://doi.org/10.1016/j.ejmg.2014.10.004 PMid:25449138

57. Sun MY, Zhang L, Shi SL, Lin JN. Associations between methylenetetrahydrofolate reductase (MTHFR) polymorphisms and non-alcoholic fatty liver disease (NAFLD) risk: A metaanalysis. PLoS One. 2016;11(4):e0154337. https://doi. org/10.1371/journal.pone. 0154337

PMid:27128842

58. Wang W, Jiao XH, Wang XP, Sun XY, Dong C. MTR, MTRR, and MTHFR gene polymorphisms and susceptibility to nonsyndromic cleft lip with or without cleft palate. Genet Test Mol Biomarkers. 2016;20(6):297-303. https://doi.org/10.1089/gtmb.2015.0186 PMid:27167580

59. Zhi X, Yang B, Fan S, Li Y, He M, Wang D, et al. Additive interaction of MTHFR C677T and MTRR A66G polymorphisms with being overweight/obesity on the risk of Type 2 diabetes. Int J Environ Res Public Health. 2016;13(12):1243. https://doi. org/10.3390/ijerph13121243

PMid:27983710

60. Khaligi K, Cheng G, Mirabbasi S, Khaligi B, Wu B, Fan W. Opposite impact of methylene tetrahydrofolate reductase C677T and methylene tetrahydrofolate reductase A1298C gene polymorphisms on systemic inflammation. J Clin Lab Anal. 2018;32(5):e22401. https://doi.org/10.1002/jcla.22401 PMid:29396861

61. Sorokina I, Myroshnychenko M, Sherstiuk S, Zubova Y, Nakonechna S, Panov S. The morphological picture of local immune responses in the kidneys, ureters and bladder of the foetuses and newborns, who developed in conditions of maternal preeclampsia. Georgian Med News. 2018;275:123-32. PMid:29578438

62. Wan L, LiY, Zhang Z, Sun Z, He Y, Li R. Methylenetetrahydrofolate reductase and psychiatric diseases. Transl Psychiatry. 2018;8:242. https://doi.org/10.1038/s41398-018-0276-6 PMid:30397195

63. Ma LM, Yang HP, Yang XW, Ruan LH. Methionine synthase A2756G polymorphism influences pediatric acute lymphoblastic leukemia risk: A meta-analysis. Biosci Rep. 2019;39(1):BSR20181770. https://doi.org/10.1042/ BSR20181770

\section{PMid:30559146}

64. Ren ZJ, Zhang YP, Ren PW, Yang B, Deng S, Peng ZF, et al Contribution of MTR A2756G polymorphism and MTRR A66G polymorphism to the risk of idiopathic male infertility. Medicine. 2019;98(51):e18273. c10.1186/s12958-020-00649-1 PMid:31860974

65. Tykhonova TM. Skin lesions in diabetes mellitus: Risk factors for development, clinical manifestations, prevention and treatment. Problemi Endokrinnoi Patologii. 2019;1:121-8. https://doi. org/10.21856/j-PEP.2019.1.15

66. Lupi-Herrera E, Soto-López ME, Lugo-Dimas AJ, NúñezMartínez ME, Gamboa R, Huesca-Gómez C, et al. Polymorphisms C677T and A1298C of MTHFR gene: Homocysteine levels and prothrombotic biomarkers in coronary and pulmonary thromboembolic disease. Clin Appl Thromb Hemost. 2019;25:1076029618780344. https://doi. org/10.1177/1076029618780344 PMid:29916259

67. Zara-Lopes T, Galbiatti-Dias AL, Castanhole-Nunes MM, Padovani-Júnior JA, Maniglia JV, Pavarino EC, et al. Polymorphisms in MTHFR, MTR, RFC1 and CBS genes involved in folate metabolism and thyroid cancer: A case-control study. Arch Med Sci. 2019;15(2):522-30. https://doi.org/10.5114/ aoms.2018.73091 PMid:30899306

68. Zhang $Y$, Zhan $W$, Du Q, Wu L, Ding $H$, Liu F, et al. Variants c.677 C>T, c. 1298A $>C$ in MTHFR, and c.66A>G in MTRR affect the occurrence of recurrent pregnancy loss in chinese women. Genet Test Mol Biomarkers. 2020;24(11):717-22. https://doi. org/10.1089/gtmb.2020.0106

PMid:33121283

69. Mahmud N, Molloy A, McPartlin J, Corbally RC, Whitehead AS, Scott JM, et al. Increased prevalence of methylenetetrahydrofolate reductase $\mathrm{C} 677 \mathrm{~T}$ variant in patients with inflammatory bowel disease, and its clinical implications. Gut. 1999;45:389-94. https://doi.org/10.1136/gut.45.3.389 PMid:10446107

70. Husemoen LL, Toft $U$, Fenger M, Jørgensen T, Johansen N, Linneberg $\mathrm{A}$. The association between atopy and factors influencing folate metabolism: Is low folate status causally related to the development of atopy? Int J Epidem. 2006;35(4):954-61. https://doi.org/10.1093/ije/dyl094

PMid: 16766537

71. Vasku V, Bienertova-Vasku J, Necas M, Vasku A. MTHFR (methylenetetrahydrofolate reductase) C677T polymorphism and psoriasis. Clin Exp Med. 2009;9(4):327-31. https://doi. org/10.1007/s10238-009-0054-0 PMid:19484352

72. van der Valk RJ, Kiefte-de Jong JC, Sonnenschein-van der Voort AM, Duijts L, Hafkamp-de Groen E, Moll HA, et al. Neonatal folate, homocysteine, Vitamin B12 levels and methylenetetrahydrofolate reductase variants in childhood asthma and eczema. Allergy. 2013;68(6):788-95. https://doi.org/10.1111/all.12146 PMid:23692062

73. Fedota AM. Genodermatoses in the Study of the Problems of Human Genetic Safety. Dissertation. Kiev; 2012.

74. Reich DE, Cargill M, Bolk S, Ireland J, Sabeti PC, Richter DJ, et al. Linkage disequilibrium in the human genome. Nature. 2001;411(6834):199-204. https://doi.org/10.1038/35075590 PMid:11346797

75. Gaughan DJ, Kluijtmans LA, Barbaux S, McMaster D, Young IS Yarnell JW, et al. The methionine synthase reductase (MTRR) A66G polymorphism is a novel genetic determinant of plasma homocysteine concentrations. Atherosclerosis. 2001;157:4516. https://doi.org/10.1016/s0021-9150(00)00739-5 PMid:11472746 